\title{
Game-changing potential of the EU's Farm to Fork Strategy
}

\author{
The European Union's new Farm to Fork Strategy will initiate several well-defined actions, but its potential to foster \\ genuine change of EU food systems depends on the resolution of four key governance challenges, and political \\ momentum during the implementation phase.
}

\author{
Hanna Schebesta and Jeroen J. L. Candel
}

T he European Union (EU)'s new Farm to Fork (F2F) Strategy ${ }^{1}$ is lauded as a major advance in European food policymaking. Published in May 2020, it represents a first step towards genuine food systems governance ${ }^{2}$ and seems well timed to address some of the most pressing environmental and public health concerns that European society faces. However, the strategy's success will ultimately depend on its implementation in the very near future. From governance and legal perspectives, we identify four major challenges that will determine whether the F2F Strategy will truly be a game-changer: the unresolved ambiguity of food sustainability, the discrepancy between policy objectives and the specific legal actions proposed, the vulnerable institutional embedding within the European Commission, and limited coordination with the EU's Member States. We conclude that the strategy's potential for fostering a genuine change of EU food systems governance will largely depend on the resolution of these challenges and the ability of the EU's leadership to continue political momentum - and this will be further challenged by the economic fallout from the COVID-19 pandemic.

\section{Journey from farm to fork}

The F2F Strategy aims to make the EU food system fair, healthy and environmentally friendly, and has been hailed as a cornerstone of the European Green Deal under the 2019-2024 European Commission. It is the first time in the history of EU food law that the union has addressed food sustainability in a comprehensive manner, from primary production to the consumer. The strategy includes ambitious and concrete targets on pesticides, fertilizers, organic farming and antimicrobial resistance to be achieved by 2030. To realize the quantitative targets, it sets out both regulatory and non-regulatory initiatives, including a legislative framework for sustainable food systems for which a proposal is expected before the end of 2023 . As such, the strategy primarily has an agenda-setting function; to show effect, the envisioned actions require translation into EU and national legislation. Specific follow-up steps are set out in an accompanying action plan ${ }^{1}$, which lists a range of legislative commitments and their timing.

The adoption of the F2F Strategy can also be seen as an attempt to create a more integrated food strategy ${ }^{3}$. At present, the food sector is regulated by a very wide range of policy domains in which the EU has exercised its legal competences over time. For example, the 2000 White Paper on Food Safety ${ }^{4}$ already coined a 'farm to table' approach, which over time morphed into 'farm to fork' and established a coherent approach to food safety to further the internal market - it did not, however, mention sustainability. Similarly, the EU has become the major venue of European agricultural and fisheries policymaking. Although the Common Agricultural Policy (CAP) is still primarily targeted at farmers, EU agricultural policy's remit has recently been broadened through the adoption of new legislation on unfair trading practices in agricultural and food supply chains ${ }^{5}$. Other relevant policy areas in which the EU holds broad competence include the Common Commercial Policy and competition law, environmental policy and consumer protection.

Despite high expectations for the F2F Strategy's impact, we identify four key challenges that will determine its ultimate success.

\section{Unresolved ambiguity of food sustainability}

A key challenge in the implementation of the F2F Strategy is the unresolved ambiguity of what is meant by 'food sustainability' or a 'sustainable food system'. The European Commission does not define sustainability or even acknowledge that it is a multidimensional concept, instead pointing to the range of environmental, health, social and economic benefits of shifting towards a sustainable food system. As a consequence, the concept remains rather ill-defined in the F2F Strategy, appearing as a panacea without clear conceptual boundaries. This is problematic for two reasons.

First, food sustainability has come to serve as a container concept, covering a broad range of objectives. There is a real concern for the emergence of policy incoherencies, as policy actions that contribute to realizing some of the underlying objectives of the strategy may impede or result in a step backwards for others. For example, stimulating grass-based ruminant systems (instead of feeding farm animals with human-edible biomass) may be recommendable from a sustainable land-management perspective, but there is a potential trade-off with ambitions to reduce greenhouse gas emissions and, possibly, to improve biodiversity ${ }^{6}$. Similarly, for the Sustainable Development Goals, this risk has recently been demonstrated; in the case of the goal of quality, reliable, sustainable and resilient infrastructure (Sustainable Development Goal 9.1), the indicators seem to prioritize social and economic issues over environmental impacts ${ }^{7}$.

Second, whereas the elusiveness of the concept of food sustainability serves the European Commission to find resonance among diverse stakeholder groups, food system actors may have fundamentally different ideas about what future food system they envision - or how to get there ${ }^{8}$. Ignoring or depoliticizing these differences may ultimately backfire and reduce the strategy's perceived legitimacy.

Policy objectives versus legal actions The discrepancy between the ambitions of the policy objectives of the F2F Strategy and the limited ambit of the 27 specific legal actions proposed, outlined in Table 1, creates a challenge. The strategy is divided 
Table 1 | Overview of the 27 proposed specific action points by intervention type and topic

\begin{tabular}{ll}
$\begin{array}{l}\text { Intervention type cluster and target } \\
\text { topic }\end{array}$ & Action proposed \\
\hline Systemic & \\
\hline $\begin{array}{l}\text { Systemic approach to sustainability } \\
\text { Crisis response capacity }\end{array}$ & $\begin{array}{l}\text { Proposal: legislative framework for sustainable food systems } \\
\text { Enabling framework }\end{array}$ \\
\hline Business responsibility & Improve corporate governance framework \\
\hline Competition law & $\begin{array}{l}\text { Develop EU code on responsible business and marketing } \\
\text { conduct }\end{array}$ \\
\hline Public procurement & Clarify competition law on sustainability in collective actions \\
\hline Sustainable labelling scheme & Enhance cooperation of primary producers \\
\hline Advertisement & $\begin{array}{l}\text { Minimum mandatory criteria for sustainable consumption in } \\
\text { food procurement }\end{array}$ \\
\hline & Proposal: sustainable food labelling framework \\
\hline
\end{tabular}

\section{Farming}

CAP

Pesticides

Animal welfare

Feed additives

Carbon farming

Food and Health

Nutrition

\begin{tabular}{|l|l|}
\hline & $\begin{array}{l}\text { Nutrition profiles to restrict salt, sugar, fat } \\
\text { Proposal: mandatory nutrition labelling }\end{array}$ \\
\hline Food Safety & Revision of food contact material legislation \\
\hline Food quality & \\
\hline EU marketing standards & Revision of EU marketing standards \\
\hline Food fraud & Proposal: origin indication \\
\hline Food waste & Enhance enforcement against food fraud \\
\hline & Targets for food waste reduction \\
\hline & Revision of date marking \\
\hline
\end{tabular}

The text of the F2F Strategy is accompanied by a draft action plan. Many objectives and topics mentioned in the strategy are not translated into specific actions.

into four clusters: sustainable food production; sustainable food processing and distribution; sustainable food consumption; and food loss and waste prevention.

Whereas these clusters contain some clear targets to be achieved by 2030 - a reduction of chemical and hazardous pesticides by $50 \%$, a reduction of fertilizer use by $20 \%$, a quota of $25 \%$ of EU arable land dedicated to organic farming and a reduction of sales of antimicrobials by $50 \%$ - the goals in other areas are much more abstract, and some topics are outright missing (for example, biotechnology, such as genetic modification). While the action list shows a number of interventions that target a diversity of specific issues, many of the strategy's promises are not translated into action points.

A case in point is the mismatch between policy objectives and legal actions is the CAP, which makes up approximately $26 \%$ of the EU budget (2018). Whereas the commission states that the new CAP, currently being negotiated, "aims to help farmers to improve their environmental and climate performance" through a range of policy innovations, the action plan contains few substantive efforts in this respect. In terms of specific legal actions, the commission has high hopes to influence the national strategic plans that Member States will need to draft under the new CAP, setting out how they intend to meet nine EU-wide (sustainability) objectives stated under the CAP proposal. However, commentators have already shared their worries about the lack of ambition among Member State governments, as well as the relabelling of CAP instruments as 'climate expenditure' without having substantial climate impacts ${ }^{9}$.

The most systemically relevant action is the proposed legislative framework for sustainable food systems that aims to promote policy coherence at EU and national levels. This framework could prove the embryo of a truly integrated food policy, drawing up common definitions, principles and requirements, and addressing the responsibilities of all actors in the food system. That said, the strategy leaves open what such a framework would look like in practice, and as the proposal will only be tabled in 2023, much depends on the sustainability appetite of EU lawmakers three years from now. Even in a favourable climate, one can presume that it will not be passed as law under the mandate of the incumbent commission.

\section{Complex institutional embedding}

Apart from policy content, there are institutional challenges to the strategy's success. A first challenge is the institutional embedding of the strategy with the European Commission's Directorate-General for Health and Food Safety. Even though other Directorate-Generals were involved in the strategy's design, food-related turf wars within the commission may seriously hamper the implementation process. The Directorate-General for Agriculture and Rural Development has, for example, traditionally been very receptive to farmers' interests and shielded agricultural 
policymaking from the involvement of other Directorate-Generals ${ }^{10}$. Similarly, in the revision of the Green Procurement Criteria for food, the Directorate-General for Environment exhibited reluctance to go beyond a purely 'green' environmental institutional mandate and address other sustainability dimensions such as socio-economic considerations ${ }^{11}$. Similar institutional tensions exist between European Parliament committees, where differences in political viewpoints constitute a further challenge.

Such bickering over mandates and possibly legal competencies ${ }^{12}$, as well as associated conflicting policy ideas, risks the potential for developing a coherent and effective policy mix. As a way forward, it would be highly recommended for such institutional tensions to be addressed directly in the overarching sustainable food system legislative proposal by facilitating inter- and intra-institutional cooperation.

\section{Coordination with the Member States}

Apart from a horizontal coordination challenge, there is a similar vertical competence and coordination challenge between the EU level and the Member State governments. As food system drivers and impacts are transboundary, effective multilevel governance arrangements are indispensable. In some fields, such as human health, tax policy (to (dis)incentivize certain food products) or the CAP national strategic plans, Member States are in the lead to make policy. However, many Member State governments are not too keen on taking far-reaching environmental measures, particularly when these hurt vested industries. In addition, Member States have already raised concerns about possible violations of the subsidiarity principle that states that the EU can act only where a proposed action cannot be sufficiently achieved at national level. For example, the Dutch Minister of Agriculture, Carola Schouten, stated that whereas she shared the strategy's objectives, she felt that the proposed action of making "recommendations to each Member State addressing the nine specific objectives of the Common Agricultural Policy" raised questions about the policy's new emphasis on subsidiarity ${ }^{13}$. Successful coordination with the Member States is therefore a prerequisite without which there is a real risk of a watering down of the strategy's ambitions in the Member State implementation phase.

\section{Conclusions}

The F2F Strategy may be the first step towards a truly integrated and effective sustainable food system strategy, but to become a real game-changer, the EU institutions will have to find ways to navigate through the substantive and institutional challenges elaborated here.

In terms of content, the strategy may prove an effective way of initiating well-defined actions that are capable of consensus. However, to strengthen the strategy's social basis, the European Commission will have to move beyond the narrow view of the food system transition as "a 'first mover' opportunity for all actors in the EU food chain"'. While capable of creating opportunities, a transition also involves economic losers, in terms of businesses, sectors and regions. Without addressing the latter as much as the (potential) winners, the strategy risks stranding in the council and parliament. Moreover, to decide on the desired directions of a European food system transition in a more legitimate manner, EU leaders will have to find ways to foster genuine food democracy within and across levels of government. Without the involvement and commitment of European food producers, processors, retailers and consumers, the F2F Strategy is unlikely to bring about much-needed change. Recent food democracy initiatives, such as food policy councils or citizen summits, offer promising ways of "making choices when values and interests come into conflict and when the consequences of decisions are uncertain" ${ }^{14}$. The announced legislative framework for sustainable food systems may be an appropriate tool to create a framework for strengthened food democracy at the EU level.

Ultimately, the strategy's success will be contingent on the political willingness of the European Parliament and Council to support the European Commission's high levels of ambition, and the capacity to reconcile opposing interests between Member States, political groups and interest groups. The ability of the EU's leadership to maintain political momentum during the anticipated economic downturn following the COVID-19 pandemic will be decisive in this respect.

\section{Hanna Schebesta (D) $₫$ and Jeroen J. L. Candel (D) \\ Wageningen University and Research, Wageningen, the Netherlands. \\ $\bigotimes_{\mathcal{e} \text {-mail: Hanna.Schebesta@wur.nl }}$}

Published online: 14 October 2020

https://doi.org/10.1038/s43016-020-00166-9

References

1. Communication from the Commission to the European Parliament, the Council, the European Economic and Social Committee and the Committee of the Regions: A Farm to Fork Strategy for a fair, healthy and environmentally-friendly food system COM/2020/381 final (European Commission, 2020).

2. Jackson, P. et al. A Sustainable Food System for the European Union (SAPEA, 2020); https://doi.org/10.26356/sustainablefood

3. Candel, J. J. L. \& Pereira, L. Environ. Sci. Policy 73, 89-92 (2017).

4. White Paper on Food Safety COM/99/0719 (European Commission, 2000).

5. Directive (EU) 2019/633 of the European Parliament and of the Council of 17 April 2019 on Unfair Trading Practices in Business-to-Business Relationships in the Agricultural and Food Supply Chain OJ L111/59 (European Parliament and the Council, 2019).

6. Van Zanten, H. H. E., Van Ittersum, M. K. \& De Boer, I. J. M. Glob. Food Sec. 21, 18-22 (2019).

7. Zeng, Y. et al. Nat. Sustain. https://doi.org/10.1038/s41893-0200555-0 (2020).

8. Candel, J. J. L., Breeman, G. E., Stiller, S. J. \& Termeer, C. J. A. M. Food Policy 44, 47-58 (2014).

9. Matthews, A. Climate mainstreaming the CAP in the EU budget: fact or fiction. Cap Reform http://capreform.eu/climatemainstreaming-the-cap-in-the-eu-budget-fact-or-fiction/ (2020). 10. Lynggaard, K. \& Nedergaard, P. J. Eur. Integr. 31, 291-309 (2009). 11. Schebesta, H. Eur. J. Risk Regul. 9, 316-328 (2018).

12. Schebesta, H. \& Purnhagen, K. EU Food Law (Oxford Univ. Press, in the press).

13. Kamerbrief met agenda videoconferentie EU-landbouwministers 8 juni 2020. Rijksoverheid https://go.nature.com/3jdRFpL (2020). 14. Hassanein, N. J. Rural Stud. 19, 77-86 (2003).

Acknowledgements

We are grateful to L. Batten for helpful comments. Any errors remain the sole responsibility of the authors.

Author contributions

The article is the equal and joint responsibility of the authors.

Competing interests

The authors declare no competing interests. 